\title{
DETERMINANT FACTORS OF LENGTH OF STAY AMONG UNDER-FIVE CHILDREN WITH PNEUMONIA DISEASES: A LITERATURE REVIEW
}

\section{Casman', Nani Nurhaeni ${ }^{2}$}

\author{
1 Department of Pediatric Nursing, RS Husada School of Health Science \\ 2 Department of Pediatric Nursing, Universitas Indonesia \\ * Correspondence: nerscasman@gmail.com
}

\begin{abstract}
Pneumonia is a public health problem in the worldwide, in Indonesia around $22.7 \%$ of under-five child mortality caused by pneumonia. The study aimed at identifying factors associated with length of stay among children under five years with pneumonia. This literature review conducted using four databases including ScienceDirect, EBSCOhost, Clinical Key, and SpringerLink by combining keywords: length of stay; hospitalization; length in hospital; pneumonia; child; pediatric; pediatric; and children. The results showed that the period of length of stay pneumonia ranged 1 to 21 days. Some factors which extend the inpatient period including family history with cigarette smoke, less of nutrient and influenza. Meanwhile, some factors were noted to decrease the length of stay pneumonia among children, including early vaccine, examination, and family empowerment through health education. Mostly factors could reduce or increase LOS pneumonia in children under five years, depending on family factors. It requires further research; it is necessary to consider the effect of family education to decrease LOS pneumonia of children.
\end{abstract}

Keywords: Determination factor, Length of Stay, Pneumonia, Children

International Journal of Nursing and Health Services (IJNHS), September 2019, Volume 2, Issue 3; Page 80-88

Received: 10 March 2019; Revised: 15 April 2019; Accepted: 22 April 2019

DOI: http//doi.org/10.35654/ijnhs.v2i3.125

\section{Introduction}

A number of $80 \%$ of under-five child mortality in the world occurs in Africa and Southeast Asia (1). The data shows that the death caused by pneumonia (19\%), diarrhea (17\%), prematurity and infection or sepsis $(10 \%)$. The pneumonia is the leading cause of under-five child mortality (2). Indonesia also faces the same condition in which $21.7 \%$ of under-five child mortality caused by pneumonia (3). 15\%-30\% of children with pneumonia are necessarily hospitalized (4). Every year, the total of hospitalized children with pneumonia increases. In 2003, it was $2.89 \%$, and the number increases by $4.02 \%$ in 2007 (5). Research states that the inpatient period of pneumonia sufferers is generally 5-8 days (6). Meanwhile, another International Journal of Nursing and Health Services (IJNHS), Volume 2, Issue 3, September 201980 
research indicates that the length of hospital stay (LOS) of under-five children with pneumonia is $0.7 \%$ (453 of 627 ) or 1-5 days (7).

LOS will make parents anxious, and after the children discharge, the parents tend to blame themselves or feel depressed. After three days of inpatients, about $0.25 \%$ (27 of 107) of parents whose children are hospitalized (in a non-intensive room) will feel traumatic (8). There are some factors influencing pneumonia on children, and the most influential factors are age, breast milk, nutrient status, and smoking habit (9). The factors of pneumonia that possibly prolongs LOS must be balanced with the efforts to decrease LOS. The shots are likely performed through adequate therapies (such as oxygen, inhalation, and antibiotic giving) (2).

\section{Objectives}

This study aimed at identifying the influencing factors of LOS among children with pneumonia

\section{Methods}

\subsection{Eligibility criteria}

The Inclusion criteria of the study, including full-text published in the English language. Studies focused on factors associated with pneumonia in under-five years were involved in this study.

\subsection{Search method}

A literature review conducted in 2018, and keywords including "length of stay," "pneumonia," and "children." The article search is limited in only research articles, articles written in English, and articles published in 2014-2018 or the last five year. The search conducted from 4 databases: ScienceDirect, EBSCOhost, Clinical Key, dan SpringerLink.

\subsection{The article selection}

The articles selected by employing adaptation of PRISMA flow chart model (10). The article search was conducted in three steps. The research result shows online database $(\mathrm{n}=1.016)$. The first step was examining titles of the articles and eliminating the articles with similar titles $(n=90)$. The second step was reading the appropriateness between titles and criteria $(n=8)$. The inclusion criteria were: a) the original articles; b) pure pneumonia without another illness/accompanying condition such as nerve disorder; and c) caring conducted in ordinary nursing rooms (not NICU/PICU). Meanwhile, the exclusion criteria were: a) children with particular need; and b) mentioning the age of the respondents with pneumonia or infectious respiratory disease in the articles. 


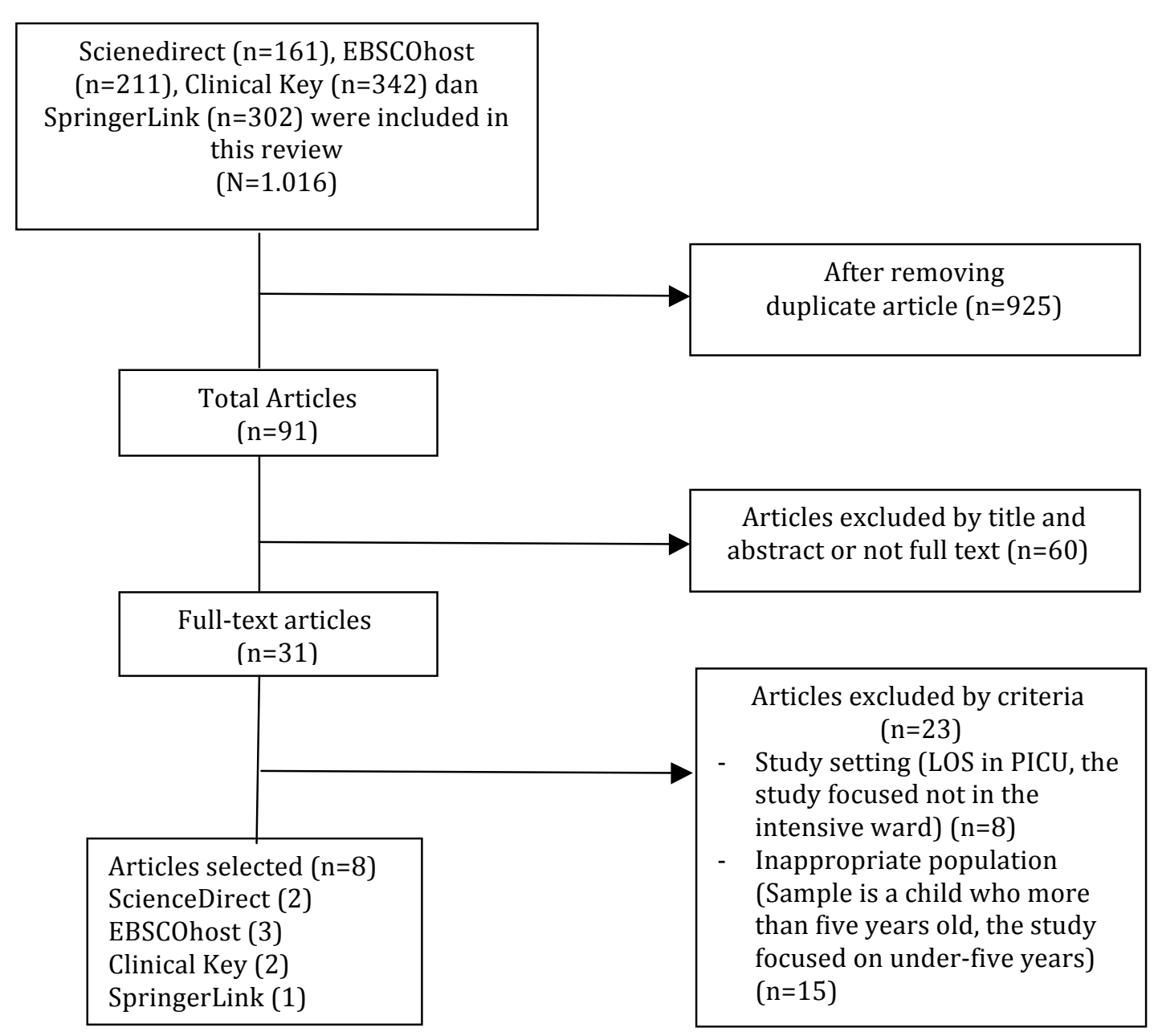

Picture 1. selection process of the articles

\section{Results}

This research collects 1,016 articles, but only 23 of them are analyzed. Then, only eight suitable studies are relevant to our inclusion criteria

\subsection{Characteristics of the study}

Eight related articles were reviewed in this study. Three studies employed in a prospective cohort study (11-13), two studies focused on retrospective with Cohort (14-15), and two articles apply case-control (1617), Only 1 study conducted the quasi-experimental design (18). All of the eight analyzed articles focus on the duration of the inpatients of pneumonia, including strategies to decreases LOS or factors extending LOS of children with pneumonia.

\subsection{Differenciance Length of Stay}

The average LOS of children with pneumonia is different in each article. It can be influenced by the total of passive smokers living in the same house. The individual who exposed the cigarette smoke was longer of LOS than those who did not disclose the smoke (11). They have a weak condition 
also showed longer LOS approximately 7.5 days. Meanwhile, on average, LOS of children with good condition (i.e., adequate nutrient and emergence of positive indication during the inpatient period) is five days (12).

Table 1. Summary of included articles

\begin{tabular}{|c|c|c|c|}
\hline Citation & Design & Sample & Finding \\
\hline Ahn et al., 2015 (11) & $\begin{array}{l}\text { Prospective since } \\
\text { January 2010-June } \\
\text { 2012, the used } \\
\text { questioner }\end{array}$ & $\begin{array}{l}\text { All children under } 18 \text { years } \\
\text { on three hospitals in USA } \\
\text { pneumonia (n: } 2.358 \\
\text { children) }\end{array}$ & $\begin{array}{l}\text { The result showed that } \\
\text { exposure secondhand smoke } \\
\text { has more long of stay compare } \\
\text { than no smoke }(64,4<67,4 \\
\text { hour). }\end{array}$ \\
\hline $\begin{array}{l}\text { Durigon et al., } 2015 \\
\text { (12) }\end{array}$ & $\begin{array}{l}\text { Prospective since } \\
\text { March 2008-February } \\
\text { 2010, used lab. test } \\
\text { (polymerase chain } \\
\text { reaction ) }\end{array}$ & $\begin{array}{l}\text { Children under two years in } \\
\text { third hospitals of Brazil ( } \mathrm{n}= \\
760 \text { children) }\end{array}$ & $\begin{array}{l}\text { The result showed that more } \\
\text { good condition of the child, the } \\
\text { LOS of pneumonia shorter. }\end{array}$ \\
\hline Nair et al., 2016 (14) & $\begin{array}{l}\text { A retrospective study } \\
\text { (SMR01 from 2000- } \\
\text { 2012) }\end{array}$ & $\begin{array}{l}153.636 \text { children have been } \\
\text { hospitality in hospital of } \\
\text { Skotlandia }\end{array}$ & $\begin{array}{l}\text { The result showed that early } \\
\text { vaccine significant to decrease } \\
\text { LOS of pneumonia. }\end{array}$ \\
\hline $\begin{array}{l}\text { Zhang et al., } 2014 \\
\text { (17) }\end{array}$ & Observational study & $\begin{array}{l}\text { ( } \mathrm{n}=22 \text { child in the } \\
\text { intervention group) BAL } \\
\text { gave three days since first } \\
\text { day, }(\mathrm{n}=13 \text { child in control } \\
\text { group) BAL given after } \\
\text { three days }\end{array}$ & $\begin{array}{l}\text { The result showed that early } \\
\text { BAL significant to decrease } \\
\text { LOS of pneumonia. }\end{array}$ \\
\hline $\begin{array}{l}\text { Zhang et al., } 2016 \\
\text { (15) }\end{array}$ & $\begin{array}{l}\text { A retrospective study } \\
\text { (collecting data was } \\
\text { 2005-2011) }\end{array}$ & $\begin{array}{l}69.952 \text { children have been } \\
\text { hospitalized }\end{array}$ & $\begin{array}{l}\text { The result showed that } \\
\text { pneumonia with influenza has } \\
\text { more short compare than } \\
\text { pneumonia with other } \\
\text { complication. }\end{array}$ \\
\hline $\begin{array}{l}\text { Roussel et al., } 2018 \\
\text { (13) }\end{array}$ & $\begin{array}{l}\text { An observational } \\
\text { study from October } \\
\text { 2016- March } 2017 \text { in } \\
\text { France }\end{array}$ & $\begin{array}{l}\text { Children under } 15 \text { years } \\
\text { ( } n=556 \text { children) }\end{array}$ & $\begin{array}{l}\text { The result showed that } \\
\text { separated bed not significant } \\
\text { in LOS pneumonia }(\mathrm{p}=0,78)\end{array}$ \\
\hline Lu et al., 2018 (16) & $\begin{array}{l}\text { Case-control (data } \\
\text { collected on } 6 \\
\text { September 2016-30 } \\
\text { November } 2016 \text { at } \\
\text { 51hospitals in China }\end{array}$ & ( $\mathrm{n}=175$ children) & $\begin{array}{l}\text { The result showed that HAI, } \\
\text { not significant influence LOS } \\
(p=467)\end{array}$ \\
\hline $\begin{array}{l}\text { Nurhaeni et al., } 2018 \\
\text { (18) }\end{array}$ & Quasi-experiment & $\begin{array}{l}83 \text { family with a child who } \\
\text { hospitalized pneumonia }\end{array}$ & $\begin{array}{l}\text { The result showed that health } \\
\text { education for family } \\
\text { significant reduction LOS } \\
(\mathrm{p}=0,00)\end{array}$ \\
\hline
\end{tabular}


The initial vaccine, especially the pneumococcal conjugate vaccine (PCV13) can reduce LOS pneumonia; patients in the vaccine group are shorter than the final vaccine group (14). LOS of first Bronchoalveolar Lavage (BAL) group shorted than the new BAL group (7 vs. <10 days) (17). Average of LOS pneumonia with other complication more long than pneumonia with influenza $(<2,3-8,0$ vs. $2,2-6,1$ days $)$ (15). LOS of intervention group is shorted than the control group with an average of LOS of the intervention group with education is 4.64 days, but that of the group without knowledge is 5.29 days (18).

The average of LOS separated and not separated bed around 10.6-15.1 days (13); the longest LOS pneumonia is pneumonia with HealthcareAssociated Infection (HAI), LOS is 21 days (16).

\subsection{Determinant Factors LOS pneumonia}

All of the analyzed articles $(n=8)$ employ a control group as a comparison to investigate which group has shorter LOS. LOS influenced by some factors, including factors that can decrease LOS or have a risk of extending LOS. Three identified factors continue LOS, including cigarette smoke exposure (11), lack of healthy condition, adverse symptoms of pneumonia, and lack of nutrients during the caring period (12). Also, pneumonia with influenza will extend caring duration (15).

Some efforts to reduce LOS might be made through an initial radiological examination (Bronchoalveolar Lavage) to determine the level of dangerous conditions of pneumonia (17). Early pneumococcal conjugate vaccine (PCV13), and family empowerment by giving health education. These strategies are proven to decrease LOS of children with pneumonia (18) significantly. However, two factors do not influence LOS, they are the isolation of caring room (13), and HAI (16).

\section{Discussion}

LOS shows that inpatient duration (long of days) of a hospitalized child is usually presented in days from calculating the difference between the date of discharge and date of occupying. The data is recorded in the medical record (19). LOS can worsen patients' quality of life (20), whereas the shorter caring duration can decrease the risk of nosocomial infection (21). The analysis of eight articles reveals that the minimal LOS is 2.2 days, and the maximum caring duration is $>10$ days. LOS in each country is different; the shortest LOS occurs in Scotland and the US, which has a treatment duration of 1-4 days. LOS is happening in Indonesia, which has a period of 4-5 days, and the highest LOS is in France, China, and Brazil, which has a duration of 2.2-10 days.

Pneumonia is an acute respiratory infection that influences the lungs. Human lungs consist of a small bladder called alveoli, which function to convert $\mathrm{O}_{2}$ and $\mathrm{CO}_{3}$ in the lungs. When pneumonia attacks, alveoli are fulfilled by suppuration and liquid. As a result, the breath feels hurt, and the incoming air is limited (2). Cigarette smoke will undoubtedly obstruct the function of the lungs. This condition will result in children's lousy health because it causes a worse situation; for example, breath 
becomes tight. The state becomes worse if the children have a lack of nutrients during the caring period, and thus, they have no energy to form an antibody. Moreover, oxygen coming to their body declines if they suffer from influenza. As a result, their caring period will be longer.

Parents' ability required family involvement to reduce LOS because the nursing care process requires family involvement when arranging nursing plans to implement (22). Pneumonia that occurs in 1 to 4 -year-old children are influenced by parents' caring activities, especially mother. A mother has a significant role in taking care of sick under-five children because she is the children's primary caregiver. Also, a preventive effort is compulsorily performed by a mother, i.e., giving immunization or ensuring the environment and habit of healthy living (23). Therefore, giving early vaccine will succeed if the mother has good knowledge of benefit and schedule of giving the vaccine.

Moreover, a lack of experience will undoubtedly influence the mother's way of taking care of their children. She will be confused about taking responsibility, and even inability to identify indications and general danger signs of pneumonia. As a result, those problems worsen the children's condition becomes worse.

A mother's lack of knowledge of pneumonia is possibly solved by providing health education. Donovan's research about the pilot randomized controlled trial in Mukono Uganda involves 129 respondents. The study aims to compare the level of understanding of pneumonia in pre and post-education period. The study involved an experimental group and a control group. The control group received only a oneday training program while the experimental group received education program by using videos on Smartphones media. The result shows that there is no significant difference between the two groups. However, the two groups increase their understanding. The hospital cost of the control group is lower (24).

Health education is a process of learning health that possibly changes the attitude and increases the awareness of health problem and factors influencing health (25). There are several goals of giving health education including a growing understanding of children and family health, motivating the ways to communicate with health professionals, and overcoming health problems. Furthermore, health education supports parent involvement in independent-caring intervention. This strategy enhances the skills to apply in primary nursing care (26).

The argument reinforcing this goal states that education might provide information, motivation, and influence on people to change their lifestyle (25).

Health education must be given during the period of treatment, until the discharge of the child from the hospital.

Furthermore, health education must be carried out starting from the beginning of the administrative process to the schedule of home visits when the children are at home (27).

\section{Conclusion}

The analysis of eight articles reveals that health education for parents, particularly for mother, is the best way to decrease LOS of children with pneumonia. 
It cannot be separated from the fact that children (especially under-five) are still dependent on their parents. A mother's knowledge is expected to improve her children with pneumonia. Finally, she can recognize the dangerous symptoms of pneumonia and determine the appropriate treatment for pneumonia (initial radiology examination).

\section{Recommendation}

Education is possibly provided by using some media, but it requires comparative research to examine the most effective education media to decrease LOS of children with pneumonia.

\section{References}

1. World Health Organization. Children: Reducing mortality [Internet]. 2017. Available from: http://www.who.int/news-room/fact-sheets/detail/childrenreducing-mortality

2. World Health Organization. Pneumonia: The forgotten killer of children [Internet]. $2015 . \quad$ Available from: http://www.who.int/maternal_child_adolescent/documents/9280640489/en/

3. Badan Penelitian dan Pengembangan Kesehatan Kementrian Kesehatan Republik Indonesia. Riset kesehatan dasar 2013 [Internet]. 2013. Available from: http://www.depkes.go.id/resources/download/general/Hasil Riskesdas 2013.pdf

4. Kementrian Kesehatan Republik Indonesia. Pneumonia, penyebab utama kematian balita [Internet]. 2009. Available from: http://www.depkes.go.id/article/view/410/pneumonia-penyebab-kematianutama-balita.html

5. Moraes D, Hong T, Todd M, Palma M, Namaan E. Diseases Pneumonia hospitalization in Brazil from 2003 to 2007. International Journal of Infectious. 2012;16,(2): e583-e590.

6. Calzada SR, Martı R, Romero MJC, Mene R. Empiric treatment in hospitalized community-acquired pneumonia. Impact on mortality, length of stay. Respiratory Medicine. 2007;101, 1909-1915.

7. Araujo, N. De, Morganna, E., Maria, G., Costa, C., Figueroa, D., \& Ii, P. Hospitalizations due to primary care - sensitive conditions among children under five years of age: cross - sectional study Internações por condições sensíveis à atenção primária em crianças menores de cinco anos: estudo transversal. Sau Paulo Medical Journal . 2017;135(3):270-6.

8. Franck LS, Wray J, Gay C, Dearmun AK, Lee K, Cooper BA. Predictors of parent post-traumatic stress symptoms after child hospitalization on general pediatric wards: A prospective cohort study. International Journal of Nursing Studies. 2014; $\mathrm{xx} \quad(\mathrm{x}), \quad 1-12 . \quad$ Available http://dx.doi.org/10.1016/j.ijnurstu.2014.06.011

9. Hartati S, Nurhaeni N, Gayatri D. Faktor risiko terjadinya pneumonia pada anak balita. Jurnal Keperawatan Indonesia. 2008;1000:13-20. 
10. Liberati, A., Altman, D.G, Tetzlaff, J., Mulrow, C., Gotzsche, P.C., Loannidis, J.P.A., Clarke, M., Devereaux, P.J., Kleijnen, J. \& MD. The PRISMA statement for reporting literature reviews and meta-analyses of studies that evaluate health care interventions: Explanation and elaboration. J Clin Epidemiol. 2009;62(10):1-34.

11. Ahn A, Edwards KM, Grijalva CG, Self WH, Zhu Y, Chappell JD, et al. Secondhand Smoke Exposure and Illness Severity among Children Hospitalized with Pneumonia. J The Journal of Pediatrics; 2018;167(4):869-874.e1. Available from: http://dx.doi.org/10.1016/j.jpeds.2015.06.049

12. Durigon, S., G., Bruna, D., Oliveira, L., Carolina, M., Felicio, C., Finelli, C., \& Negra, R. Poor Outcome of Acute Respiratory Infection in Young Children with Underlying Health Condition in Brazil. International Journal of Infectious Diseases. 2018;34(2015):3-7.

13. Roussel A, Michel M, Lefevre-utile A, Pontual L De, Faye A. Impact of social deprivation on length of stay for common infectious diseases in two French university-affiliated general pediatric departments. Archives de Pédiatrie. 2018;25(6):359-64. Available from: https://doi.org/10.1016/j.arcped.2018.06.003

14. Nair H, Watts AT, Williams LJ, Omer SB, Simpson CR, Willocks LJ, et al. Pneumonia hospitalizations in Scotland following the introduction of pneumococcal conjugate vaccination in young children. BMC Infectious Diseases; 2016;1-11. Available from: http://dx.doi.org/10.1186/s12879-0161693-x

15. Zhang X, Zhang J, Chen L, Feng L, Yu H, Zhao G, et al. Pneumonia and influenza hospitalizations among children under 5 years of age in Suzhou, China, 2005 2011. Wiley. 2016; 29(6)1-8.

16. Lü Y, Cai MH, Cheng J, Zou K, Xiang Q, Wu JY, et al. A multi-center nested casecontrol study on hospitalization costs and length of stay due to healthcareassociated infection. Antimicrobial Resistance and Infection Control. 2018; 7(99)1-10.

17. Zhang Y, Chen Y, Chen Z, Zhou Y, Sheng Y, Xu D, et al. Effects of Bronchoalveolar Lavage on Refractory Mycoplasma Pneumonia. Respiratory Care. 2014;59(9):17.

18. Nurhaeni N, Rustina Y, Agustini N, Rosuliana NE. Impact of family empowerment model on satisfaction and children's length of stay in hospital. Enfermería clínica; 2018;28:36-40. Available from: http://dx.doi.org/10.1016/S1130-8621(18)30033-0

19. Faisal, A. Pengaruh implements clinical pathway terhadap lama hari rawat \& biaya resep pasien hernia inguinal di RS IMC Bintaro. 2015; Unpublished master's thesis of Faculty of Public Health, Universitas Indonesia, Indonesia

20. Frost P. Hospital performance: Length of stay. Melbourne: Victorian AuditorGeneral,s Office; 2016.

21. Sullivan K. 6 ways hospitals can reduce the length of stays [Internet]. 2013. Available from: https://www.fiercehealthcare.com/healthcare/6-wayshospitals-can-reduce-length-stays 
22. Hockenberry, M.J., \& Wilson D. Wong's essentials of pediatric nursing. 9th ed. Missouri: Elsevier; 2013.

23. Misdiarly. Penyakit infeksi saluran napas pneumonia pada balita, orang dewasa, usia lanjut. Jakarta: Pustaka Obor Populer; 2008.

24. Donovan JO, Kabali K, Taylor C, Chukhina M, Kading JC, Fuld J, et al. The use of low-cost Android tablets to train community health workers in Mukono, Uganda, in the recognition, treatment, and prevention of pneumonia in children under five : a pilot randomized controlled trial. Human Resources for Health; 2018;6(49)1-9.

25. Naidoo, J. \& Wills J. Foundations for health promotion. 6th ed. China: Elsevier; 2016.

26. Kyle, T. \& Carman S. Essentials of pediatric nursing. 3rd ed. China: Wolters Kluwer; 2017.

27. Borghans I, Kool RB, Lagoe RJ, Westert GP. Fifty ways to reduce the length of stay: An inventory of how hospital staff would reduce the length of stay in their hospital. Health Policy. 2012;104(3):222-33. Available from: http://dx.doi.org/10.1016/j.healthpol.2011.12.010 